\title{
Lagovirus europeus Gl.2 (rabbit hemorrhagic disease virus 2) infection in captive mountain hares (Lepus timidus) in Germany
}

\author{
Melanie Buehler ${ }^{1 \dagger}$, Sonja T. Jesse ${ }^{2 \dagger}$, Heike Kueck ${ }^{3}$, Bastian Lange ${ }^{3}$, Patricia Koenig ${ }^{4}$, Wendy K. Jo ${ }^{2}$, \\ Albert Osterhaus $^{2}$ and Andreas Beineke ${ }^{1 *}$ (i)
}

\begin{abstract}
Background: Rabbit hemorrhagic disease virus (RHDV, Lagovirus europeus Gl.1) induces a contagious and highly lethal hemorrhagic disease in rabbits. In 2010 a new genotype of lagovirus (GI.2), emerged in Europe, infecting wild and domestic population of rabbits and hares.

Case presentation: We describe the infection with a Gl.2 strain, "Bremerhaven-17", in captive mountain hares (Lepus timidus) in a zoo facility in Germany. Postmortem examination revealed RHD-like lesions including necrotizing hepatitis. RT-qPCR and AG-ELISA confirmed presence of GI.2. Recombination and phylogenetic analysis grouped the identified strain with other GI.2 strains, sharing nucleotide identity of $91-99 \%$.
\end{abstract}

Conclusion: Our findings confirm that mountain hares are susceptible to Gl.2 infection, due to a past recombination event facilitating virus spillover from sympatric rabbits.

Keywords: Leporidae, Caliciviridae, Emerging infection, Phylogenetic analysis, Rabbit hemorrhagic disease virus 2, RHDV2, Lagovirus, GI.2

\section{Background}

Rabbit hemorrhagic disease virus (RHDV) is a hitherto species-specific lagovirus of the Caliciviridae family that has a single stranded, positive-sense RNA genome. RHDV has been circulating in Europe since the 1980s and infects wild and domestic rabbits (Oryctolagus cuniculus) generally older than 2 months. The virus binds to histo-blood group antigens (HBGA) and shows a tropism to hepatocytes, macrophages and endothelial cells [1-3]. Suspected viral entry sites are the tracheal and duodenal mucosa [1-4] Aside from hemorrhages in

\footnotetext{
* Correspondence: andreas.beineke@tiho-hannover.de

${ }^{\dagger}$ Melanie Buehler and Sonja T. Jesse are joint first authors

'Institute of Pathology, University of Veterinary Medicine Hanover, Foundation, Buenteweg, 1730559 Hannover, Germany

Full list of author information is available at the end of the article
}

several organs, affected rabbits show pathognomonic necrosis of hepatocytes and hyaline thrombi in renal corpuscles [4]. In 2010, a new genotype of lagoviruses, GI.2 (also known as RHDV2), with a diverse VP60 capsid protein emerged and replaced previously circulating RHDV (GI.1) strains [5-7]. This new variant causes lethal infections also in juvenile $(<2$ month old) and RHDV vaccinated rabbits [6]. After its first detection in France, GI.2 spread rapidly and infections were reported in several European countries, North America, the Middle East, and Australia [8].

The European brown hare syndrome virus (EBHSV, genotype GII.1), a genetically closely related lagovirus, causes similar lesions and mortality rates as RHDV but exclusively affects hares $[9,10]$. Lytic necrosis of liver

C C The Author(s). 2020 Open Access This article is licensed under a Creative Commons Attribution 4.0 International License, which permits use, sharing, adaptation, distribution and reproduction in any medium or format, as long as you give appropriate credit to the original author(s) and the source, provide a link to the Creative Commons licence, and indicate if changes were made. The images or other third party material in this article are included in the article's Creative Commons licence, unless indicated otherwise in a credit line to the material. If material is not included in the article's Creative Commons licence and your intended use is not permitted by statutory regulation or exceeds the permitted use, you will need to obtain permission directly from the copyright holder. To view a copy of this licence, visit http://creativecommons.org/licenses/by/4.0/ The Creative Commons Public Domain Dedication waiver (http://creativecommons.org/publicdomain/zero/1.0/) applies to the data made available in this article, unless otherwise stated in a credit line to the data. 
lobules, fatty degeneration and congestion, as well as hemorrhages are more frequently seen in EBHSV than in RHDV infections, but discriminating between the two entities solely on morphological criteria is difficult [11]. In addition to the European brown hare (Lepus (L.) europeus), EBHSV infections have been reported also in other members of the family Leporidae, such as mountain hares (L. timidus) [12], Italian hares (L. corsicanus) [13], Cape hares (L. capensis) [14] and eastern cottontail rabbits (Sylvilagus floridanus) [15]. Experimental GI.1 infections of European brown hares induces virusspecific antibodies, but fails to cause clinical symptoms in this species [9]. In a retrospective study, GI.1 was found in Iberian hares (L. granatensis) in Portugal [16]. In more recent years, GI.2 infections of one Italian hare (L. corsicanus) [17], seven Cape hares (L. capensis mediterraneus) [15] and European hares (L. europaeus) [18] have been reported in different European countries. In addition, GI.2 has been detected in European hares in Australia [19]. Infected hares were found in regions where rabbits also succumbed to GI.2 infection, suggesting viral transmission from rabbits to hares $[17,18,20]$. Recently, RHDV2 infections have been reported in mountain hares from a Swedish island [21]. Different susceptibilities of wild hare populations to GI.2 infection have been observed, most likely due to epidemiological factors such as the density of sympatric rabbits, and genetic factors such as host glycan expression for viral attachment [3, 17]. Moreover, concurrent parasitic infections or a poor nutritional state both suggest a predisposition for fatal GI.2 infections in mountain hares in Sweden [21]. The present report describes pathological findings, recombination and phylogenetic analysis of a GI.2 strain in mountain hares from an outbreak in a zoo facility in Germany.

\section{Case presentation}

In May 2017, five out of six mountain hares (Supplementary material 1) of a zoo facility in northern Germany (Fig. 1a) died acutely within 2 weeks. The hares $(\# 2,3,4)$ were not vaccinated against GI.2. The two remaining hares $(\# 5,6)$ were vaccinated (ERAVAC, Hipra, Amer, Spain) shortly after receiving the necropsy results from the first three hares, but $\# 5$ also died soon after. Necropsy of the two adult females $(\# 2,5)$ one juvenile female (\#3) and male (\#4) hares revealed a good nutritional state. The liver of all hares showed a friable consistency and a moderate to severe congestion (Fig. 1b). Further findings included diffuse congestions of lungs, kidneys and spleens. Histologic examination showed severe, panlobular necrotizing hepatitis with massive congestion and acute hemorrhages in all investigated mountain hares (Fig. 1c). The kidneys exhibited several hyaline thrombi within glomerular tufts (Fig. 1d). Viral infection was confirmed in all four examined mountain hares by RT-qPCR (forward primer: $5^{\prime}-\mathrm{ACT}$
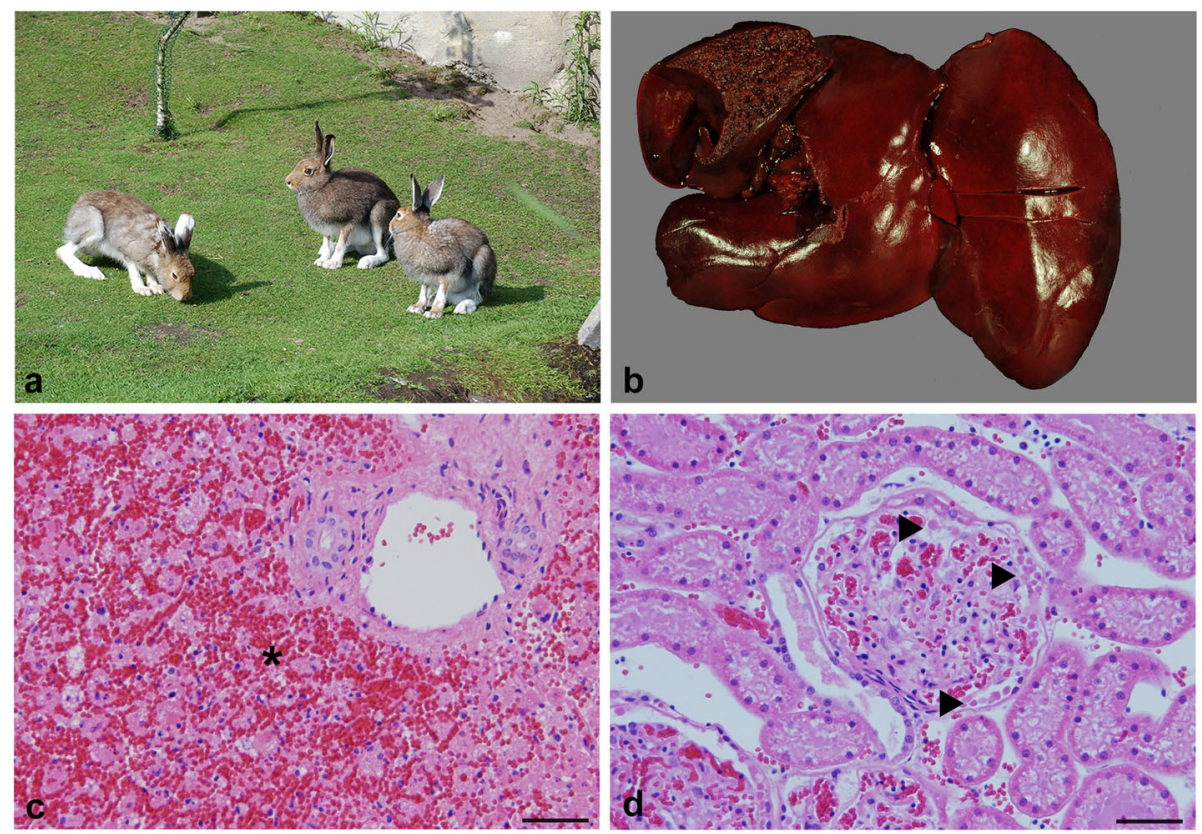

Fig. 1 Gl.2 infection in captive mountain hares (Lepus timidus). a Mountain hares in summer coat in the zoo facility in Germany. b Macroscopic picture of an infected liver. The liver of Gl.2 infected mountain hares presented with friable consistency and moderate to severe congestion. $\mathbf{c}$ Microscopic lesion within the liver included severe, diffuse, panlobular, necrotizing hepatitis with massive congestion and acute hemorrhages (*). d Hyaline thrombi $(-)$ are present within glomerular capillaries 
TGT CAG AAC TTG TTG ACA-3', reverse primer: 5'TCA GAC ATA AGA AAA GCC ATT AG-3', probe: 5'-FAM-CCA CAA GCA CGC TTG TGT ACA ACT TG-BHQ1-3') [22] and commercial antigen ELISA (Eurofins Ingenasa, Madrid, Spain) (Supplementary Material 1) of frozen liver samples, which was performed as previously described [23]. Genome was obtained by next generation sequencing (NGS) to further classify the GI.2 strain [24]. Briefly, liver tissue of animal \#5 was processed as previously described [25]. DNA library was prepared according to manufacturer's protocol (Nextera XT DNA Library Preparation Kit; Illumina) and sequenced on an Illumina NextSeq 500 sequencer with the NextSeq 500/550 High Output Kit v2 $(2 \times 150 \mathrm{bp}$ paired-end; Illumina $)$. Quality and adapter trimming, as well as reference assembly was performed using CLC Genomics Workbench (v12). The newly discovered strain was named "Bremerhaven-17" (accession number MN901451).
For recombination analysis, a set of sequences $(n=$ 388) all belonging to the GI genogroups of lagoviruses, defined by Le Pendu and colleagues [26] was used. The complete genome of "Bremerhaven-17", excluding the 5'and 3' UTR, was aligned with a set of sequences of lagoviruses of GI with nucleotide lengths over $7.239 \mathrm{bp}$ found on Genbank using the MAFFT tool (version 7) [27]. The obtained dataset was subsequently used for our recombination analysis using the RDP4 software (version 4.1) [28] applying parameters as described previously [29]. Our results correspond with the findings of previous studies $[19,29,30]$, showing a distinct recombination breakpoint in the span of 5242-5345 nt shortly before the open reading frame of the structural proteins VP60 and VP10 (data not shown), splitting the genome into non-structural and structural genes (Fig. 2a).

Prior to phylogenetic analyses of the split genome, a subset of lagovirus sequences $(n=85)$ were aligned using

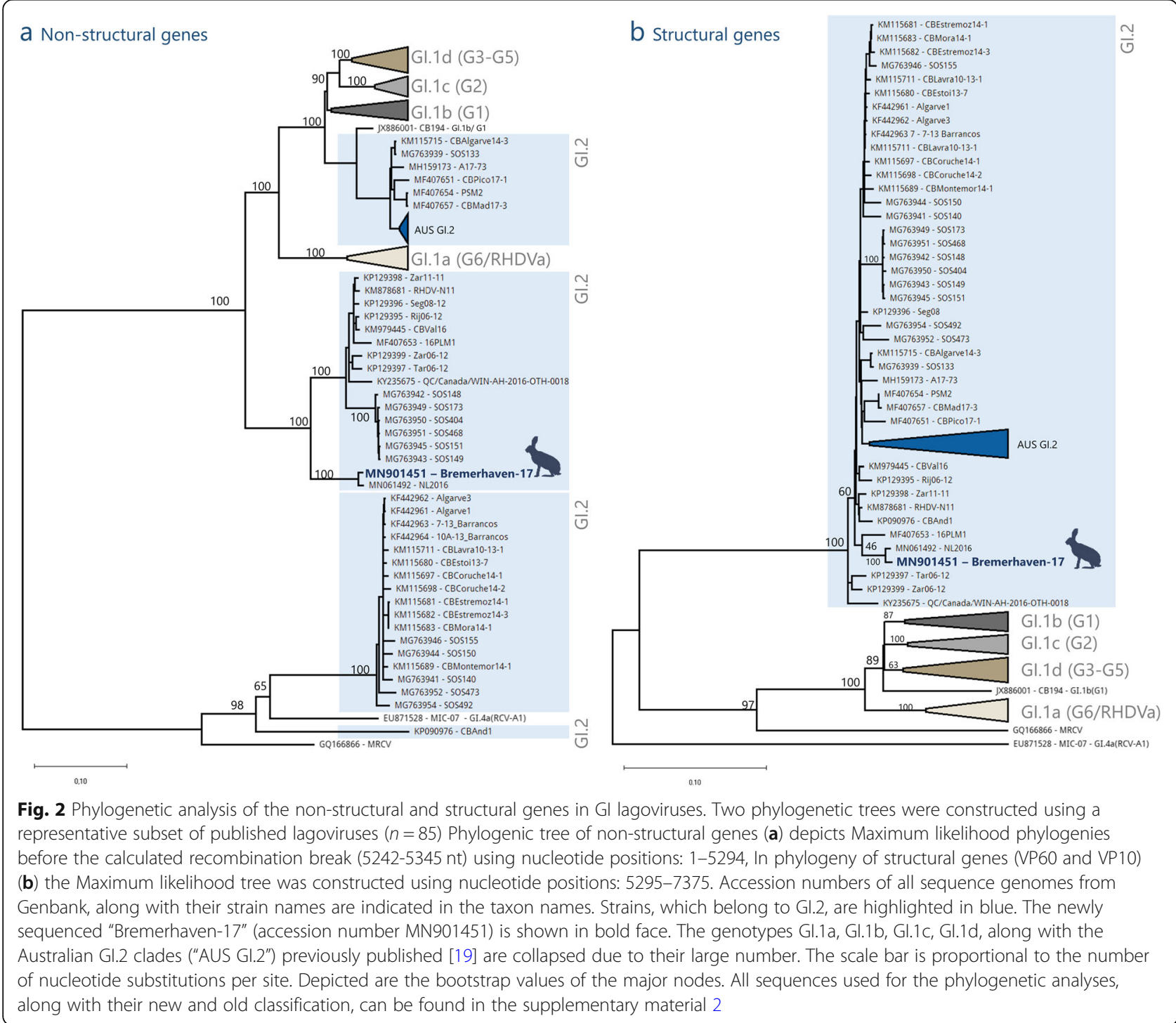


MAFFT (version 7) [27]. All 5' and 3' UTRs were cropped resulting in a uniform nucleotide length of 7375. Two phylogenetic trees representing the nonstructural genes (nucleotide position 1-5294, representing sequence before the recombination breakpoint) and structural genes (Fig. 2b) (nucleotide position 52957375, representing sequence after the recombination breakpoint) were constructed in the same manner: Phylogenies were built using MEGA X [31] with a GTR + G + I model of nucleotide substitution and a bootstrap support of 1000 replications. The structural and nonstructural genes of "Bremerhaven-17" clearly cluster with other European strains of GI.2. The highest homology (99.09\%) can be found with the strain, "NL2016", detected in a wild rabbit from the Netherlands in 2016 (accession number MN061492) [32].

\section{Discussion and conclusions}

The herein described pathological findings along with molecular and antigen detection methods confirm the sensitivity of the captive mountain hares to GI.2, as previously observed in wildlife mountain hares [21]. As observed in other vulnerable lagomorphs, all four examined mountain hares died spontaneously and showed RHD-like pathology with severe diffuse necrotizing hepatitis and circulatory disturbances $[17,18,20,21]$. In contrast to GI.1, GI.2 is known to infect rabbits younger than 10 weeks of age $[22,33]$. Correspondingly, in the present report, two juvenile (4 weeks old) mountain hares have succumbed to the virus infection. Before 2010, lagoviruses were thought to be strictly host specific in leporids, with rabbits susceptible to GI.1 and hares to EBHSV infection $[11,26]$.

The emergence of GI.2 infections of hares in Italy [17, 18, 20], Spain [18], Australia [19], Sweden [21] and the present case clearly indicate the capability of GI.2 to cross species barriers, at least within the taxonomic family Leporidae. In all reported cases, rabbits were infected with GI.2 in the same habitats, suggesting viral spillover from sympatric rabbits to hares [16-20]. In this case, an infection of GI.2 was previously detected in rabbits housed in proximity to the enclosure of the mountain hares (distance four meters) and might have caused infection in the present outbreak. In contrast to GI.2 infected wild mountain hares found in Sweden [21], these captive mountain hares were in good body condition without preexisting diseases or parasitosis, suggesting that clinical manifestation of GI.2 infection can also occur in immunocompetent mountain hares. However, high infection pressure and viral circulation in the zoo facility might have fostered a spillover of GI.2 in the described scenario.

An annuated way of constructing phylogenetic trees in GI is done by sequencing the VP60 gene coding for a major structural protein: In this case the structural genes of "Bremerhaven-17" cluster with other European GI.2 strains. This phylogeny corresponds with the phylogenetic tree found in Fig. $2 b$.

However, recent findings [19, 29, 30] have shown the importance of sequencing the non-structural genes to appreciate a better understanding of evolutionary recombination events. The non-structural genes of "Bremerhaven-17" clusters within one of the four groups previously described [34] of GI.2. (Fig. 2a). The nonstructural genes of Bremerhaven-17 share a common ancestor with G1.1a as opposed to other GI.2 strains, which share a common ancestor with non-pathogenic lagoviruses (GI.3 and GI.4). These recombination events found in the contemporary GI.2 strains clearly have led to an evolutionary advantage, however the true meaning regarding advantages in viral fitness, pathogenicity, host and tissue tropism rely on further studies.

We therefore advocate, continued monitoring, along with full genome sequencing of lagovirus cases. It is crucial to continuously determine the most common types of recombinants found in lagomorphs to predict the emergence of new recombinants and their impact on rabbit and hare populations. This can only be achieved by further characterizing full lagovirus sequence as opposed to performing phylogenetic trees using the VP60 gene, to ensure a better understanding regarding pathogenicity and epidemiology.

Results confirm that GI.2 causes disease and lethality in mountain hares [21] similar to wild and domestic rabbits and other susceptible lagomorphs [17-20]. Crossspecies transmission of GI.2 should be considered in the hygienic management of captive mountain hares, demonstrating the need for vaccination strategies for GI.2, reducing the exposure of mountain hares to rabbits and other GI.2 susceptible hare species in endemic areas. Further monitoring of wild hare populations is required to preserve the endangered species and prevent virus spread.

\section{Supplementary information}

Supplementary information accompanies this paper at https://doi.org/10. 1186/s12917-020-02386-4.

Additional file 1: Supplementary material 1. Overview of examined mountains hares from a zoo facility in Germany.

Additional file2 : Supplementary material 2. Sequences used for the phylogenetic analyses, along with their new and old classification.

\section{Abbreviations}

AG-ELISA: Antigen-Enzyme-linked immunosorbent assay; EBH: European brown hare; EBHSV: European brown hare syndrome virus; L.: Lepus; NGS: Next generation sequencing; RHDV: Rabbit hemorrhagic disease virus; RT-qPCR: Quantitative reverse transcription polymerase chain reaction 


\section{Acknowledgements}

The authors would like to thank the technical staff of the Department of Pathology and the Research Center for Emerging Infections and Zoonoses for their excellent technical assistance.

\section{Authors' contributions}

$M B$ and $S T J$ contributed equally to this paper. $M B$ and $A B$ performed the histopathological examination. STJ, WKJ and AO carried out Next Generation Sequencing, recombination analysis and the phylogenetic analysis. PK performed RT-PCR and AG-ELISA. HK and BL contributed to the data collection of hares. MB and STJ drafted the manuscript. All authors read and approved the final manuscript.

\section{Funding}

STJ was supported by the Niedersachsen-Research Network on Neuroinfectiology (N-RENNT) of the Ministry of Science and Culture of Lower Saxony and the Deutsche Forschungsgemeinschaft (DFG, German Research Foundation) - 398066876/GRK 2485/1. The funders had no role in study design, data collection and analysis, decision to publish, or preparation of the manuscript.

\section{Availability of data and materials}

The RHDV2 strain "Bremerhaven-17" is accessible in Genbank under following number: RHDV 2 strain Bremerhaven-17 MN901451.

\section{Ethics approval and consent to participate}

The authors declare that all applicable ethical guidelines were followed.

\section{Consent for publication}

Not applicable.

\section{Competing interests}

From the authors there is no conflict of interest regarding the publication of this article declared.

\begin{abstract}
Author details
'Institute of Pathology, University of Veterinary Medicine Hanover, Foundation, Buenteweg, 1730559 Hannover, Germany. ${ }^{2}$ Research Center for Emerging Infections and Zoonoses, University of Veterinary Medicine Hanover, Foundation, Buenteweg, 1730559 Hannover, Germany. ${ }^{3}$ Zoo am Meer Bremerhaven, H.-H.-Meier-Straße 7, 27568 Bremerhaven, Germany. ${ }^{4}$ Institute of Diagnostic Virology, Friedrich-Loeffler-Institut, Federal Research Institute for Animal Health, Suedufer 10, 17493 Greifswald, Insel Riems, Germany.
\end{abstract}

Received: 10 February 2020 Accepted: 22 May 2020

Published online: 27 May 2020

\section{References}

1. Nystrom K, Le Gall-Recule G, Grassi P, Abrantes J, Ruvoen-Clouet N, Le Moullac-Vaidye B, Lopes AM, Esteves PJ, Strive T, Marchandeau S, et al. Histo-blood group antigens act as attachment factors of rabbit hemorrhagic disease virus infection in a virus strain-dependent manner. PLoS Pathog. 2011;7(8):e1002188.

2. Ruvoen-Clouet N, Ganiere JP, Andre-Fontaine G, Blanchard D, Le Pendu J. Binding of rabbit hemorrhagic disease virus to antigens of the ABH histoblood group family. J Virol. 2000;74(24):11950-4.

3. Lopes AM, Breiman A, Lora M, Le Moullac-Vaidye B, Galanina O, Nystrom K Marchandeau S, Le Gall-Recule G, Strive T, Neimanis A, et al. Host-Specific Glycans Are Correlated with Susceptibility to Infection by Lagoviruses, but Not with Their Virulence. J Virol. 2018;92(4):e01759-17.

4. Abrantes J, van der Loo W, Le Pendu J, Esteves PJ. Rabbit haemorrhagic disease (RHD) and rabbit haemorrhagic disease virus (RHDV): a review. Vet Res. 2012:43:12.

5. Barcena J, Guerra B, Angulo I, Gonzalez J, Valcarcel F, Mata CP, Caston JR, Blanco E, Alejo A. Comparative analysis of rabbit hemorrhagic disease virus (RHDV) and new RHDV2 virus antigenicity, using specific virus-like particles. Vet Res. 2015;46:106

6. Le Gall-Recule G, Zwingelstein F, Boucher S, Le Normand B, Plassiart G, Portejoie Y, Decors A, Bertagnoli S, Guerin JL, Marchandeau S. Detection of a new variant of rabbit haemorrhagic disease virus in France. Vet Rec. 2011; 168(5):137-8.
7. Leuthold MM, Dalton KP, Hansman GS. Structural analysis of a rabbit hemorrhagic disease virus binding to histo-blood group antigens. J Virol. 2015;89(4):2378-87.

8. Rouco C, Aguayo-Adan JA, Santoro S, Abrantes J, Delibes-Mateos M. Worldwide rapid spread of the novel rabbit haemorrhagic disease virus (Gl. 2/RHDV2/b). Transbound Emerg Dis. 2019;66(4):1762-4

9. Capucci L, Scicluna MT, Lavazza A. Diagnosis of viral haemorrhagic disease of rabbits and the European brown hare syndrome. Rev Sci Tech. 1991; 10(2):347-70

10. Lavazza A, Scicluna MT, Capucci L. Susceptibility of hares and rabbits to the European brown hare syndrome virus (EBHSV) and rabbit haemorrhagic disease virus (RHDV) under experimental conditions. Zentralblatt fur Veterinarmedizin Reihe B Journal of veterinary medicine Series B. 1996;43(7):401-10.

11. Fuchs $A$, Weissenbock $H$. Comparative histopathological study of rabbit haemorrhagic disease (RHD) and European brown hare syndrome (EBHS). J Comp Pathol. 1992;107(1):103-13.

12. Gavier-Widen D, Morner T. Epidemiology and diagnosis of the European brown hare syndrome in Scandinavian countries: a review. Rev Sci Tech. 1991;10(2):453-8.

13. Guberti V, De Marco AM, Riga F, Lavazza A, Trocchi V, Capucci L. Virology and species conservation: the case of EBHSV and the Italian hare (Lepus corsicanus). Brescia: Vth International Congress of Veterinary Virology; 2000. p. 198-9.

14. Okerman L, Van De Kerckhove P, Osaer S, Devriese L, Uyttebroek E. European brown hare syndrome in captive hares (Lepus capensis) in Belgium. Vlaams Diergeneeskundig Tijdschrift. 1989;58:44-6.

15. Lavazza A, Cavadini P, Barbieri I, Tizzani P, Pinheiro A, Abrantes J, Esteves PJ, Grilli G, Gioia E, Zanoni M, et al. Field and experimental data indicate that the eastern cottontail (Sylvilagus floridanus) is susceptible to infection with European brown hare syndrome (EBHS) virus and not with rabbit haemorrhagic disease (RHD) virus. Vet Res. 2015;46:13.

16. Lopes AM, Marques S, Silva E, Magalhaes MJ, Pinheiro A, Alves PC, Le Pendu J, Esteves PJ, Thompson G, Abrantes J. Detection of RHDV strains in the Iberian hare (Lepus granatensis): earliest evidence of rabbit lagovirus crossspecies infection. Vet Res. 2014;45:94.

17. Camarda A, Pugliese N, Cavadini P, Circella E, Capucci L, Caroli A, Legretto M, Mallia E, Lavazza A. Detection of the new emerging rabbit haemorrhagic disease type 2 virus (RHDV2) in Sicily from rabbit (Oryctolagus cuniculus) and Italian hare (Lepus corsicanus). Res Vet Sci. 2014;97(3):642-5.

18. Velarde R, Cavadini P, Neimanis A, Cabezon O, Chiari M, Gaffuri A, Lavin S, Grilli G, Gavier-Widen D, Lavazza A, et al. Spillover events of infection of Brown hares (Lepus europaeus) with rabbit Haemorrhagic disease type 2 virus (RHDV2) caused sporadic cases of an European Brown hare syndromelike disease in Italy and Spain. Transbound Emerg Dis. 2017;64(6):1750-61.

19. Mahar JE, Hall RN, Peacock D, Kovaliski J, Piper M, Mourant R, Huang N, Campbell S, Gu X, Read A, Urakova N, Cox T, Holmes EC, Strive T: Rabbit Hemorrhagic Disease Virus 2 (RHDV2; GI.2) Is Replacing Endemic Strains of RHDV in the Australian Landscape within 18 Months of Its Arrival. J Virol. 2018:92(2):e01374-17.

20. Puggioni G, Cavadini P, Maestrale C, Scivoli R, Botti G, Ligios C, Le GallRecule G, Lavazza A, Capucci L. The new French 2010 rabbit hemorrhagic disease virus causes an RHD-like disease in the Sardinian cape hare (Lepus capensis mediterraneus). Vet Res. 2013:44:96

21. Neimanis AS, Ahola H, Larsson Pettersson U, Lopes AM, Abrantes J, Zohari S, Esteves PJ, Gavier-Widen D. Overcoming species barriers: an outbreak of Lagovirus europaeus GI.2/RHDV2 in an isolated population of mountain hares (Lepus timidus). BMC Vet Res. 2018;14(1):367.

22. Schirrmeier H.: Diagnostik der rabbit Haemorrhagic disease (RHD) und des European Brown hare Syndroms (EBHS). AVID-Methodenkandidat VIR01 2014, http://avid.dvg.net/fileadmin/Bilder/PDF_AVID_Alt/website/ Methodenkandidaten/AVID-MK-VIR01_RHD-EBHS_V_2014_11.pdf. Accessed 04.27.2020.

23. Le Gall-Recule G, Lavazza A, Marchandeau S, Bertagnoli S, Zwingelstein F, Cavadini P, Martinelli N, Lombardi G, Guerin JL, Lemaitre E, et al. Emergence of a new lagovirus related to rabbit Haemorrhagic disease virus. Vet Res. 2013:44:81.

24. Abrantes J, Esteves PJ, van der Loo W. Evidence for recombination in the major capsid gene VP60 of the rabbit haemorrhagic disease virus (RHDV). Arch Virol. 2008;153(2):329-35.

25. Jo WK, Peters M, Kydyrmanov A, van de Bildt MWG, Kuiken T, Osterhaus A, Ludlow M: The Canine Morbillivirus Strain Associated with An Epizootic in 
Caspian Seals Provides New Insights into the Evolutionary History of this Virus. Viruses. 2019;11(10):894.

26. Le Pendu J, Abrantes J, Bertagnoli S, Guitton JS, Le Gall-Recule G, Lopes AM, Marchandeau S, Alda F, Almeida T, Celio AP, et al. Proposal for a unified classification system and nomenclature of lagoviruses. J Gen Virol. 2017; 98(7):1658-66.

27. Katoh K, Rozewicki J, Yamada KD. MAFFT online service: multiple sequence alignment, interactive sequence choice and visualization. Brief Bioinform. 2019:20(4):1160-6.

28. Martin DP, Murrell B, Golden M, Khoosal A, Muhire B. RDP4: Detection and analysis of recombination patterns in virus genomes. Virus Evol. 2015;1(1): vev003.

29. Lopes AM, Blanco-Aguiar J, Martin-Alonso A, Leitao M, Foronda P, Mendes M, Goncalves D, Abrantes J, Esteves PJ. Full genome sequences are key to disclose RHDV2 emergence in the Macaronesian islands. Virus Genes. 2018; 54(1):1-4.

30. Lopes AM, Dalton KP, Magalhaes MJ, Parra F, Esteves PJ, Holmes EC, Abrantes J. Full genomic analysis of new variant rabbit hemorrhagic disease virus revealed multiple recombination events. J Gen Virol. 2015;96(Pt 6): 1309-19.

31. Kumar S, Stecher G, Li M, Knyaz C, Tamura K. MEGA X: molecular evolutionary genetics analysis across computing platforms. Mol Biol Evol. 2018;35(6):1547-9.

32. Miao Q, Qi R, Veldkamp L, ljzer J, Kik ML, Zhu J, Tang A, Dong D, Shi Y, van Oers MM et al: Immunogenicity in Rabbits of Virus-Like Particles from a Contemporary Rabbit Haemorrhagic Disease Virus Type 2 (GI.2/RHDV2/b) Isolated in The Netherlands. Viruses. 2019;11(6):553.

33. Dalton KP, Nicieza I, Balseiro A, Muguerza MA, Rosell JM, Casais R, Alvarez AL, Parra F. Variant rabbit hemorrhagic disease virus in young rabbits, Spain. Emerg Infect Dis. 2012;18(12):2009-12.

34. Silverio D, Lopes AM, Melo-Ferreira J, Magalhaes MJ, Monterroso P, Serronha A, Maio E, Alves PC, Esteves PJ, Abrantes J. Insights into the evolution of the new variant rabbit haemorrhagic disease virus (GI.2) and the identification of novel recombinant strains. Transbound Emerg Dis. 2018;65(4):983-92.

\section{Publisher's Note}

Springer Nature remains neutral with regard to jurisdictional claims in published maps and institutional affiliations.

Ready to submit your research? Choose BMC and benefit from:

- fast, convenient online submission

- thorough peer review by experienced researchers in your field

- rapid publication on acceptance

- support for research data, including large and complex data types

- gold Open Access which fosters wider collaboration and increased citations

- maximum visibility for your research: over $100 \mathrm{M}$ website views per year

At $\mathrm{BMC}$, research is always in progress.

Learn more biomedcentral.com/submissions 